\title{
Johdatus symposiumiin: kestävän talouden ja vahvan kestävyyden jäljillä
}

\section{Ville-Pekka Sorsa}

\section{Johdanto}

Kestävyys on ollut yksi merkittävimpiä iskusanoja niin tieteessä, politiikassa kuin julkisessa keskustelussakin jo vuosikymmenten ajan. Termeihin "kestävyys" ja "kestävä" törmää varsin erilaisissa asiayhteyksissä. Julkisen keskustelun perusteella kestävyydestä vaikuttaisi olevan luontevaa puhua niin teollisen ja maataloustuotannon ekologisten vaikutusten, arkkitehtuurin, valtioiden harjoittaman finanssipolitiikan kuin koko ihmiskunnan tulevaisuudenkin yhteydessä. Termin monialainen ja alati laajeneva käyttö on kuitenkin johtanut myös siihen, että kestävyys käsitteenä on pitkälti menettänyt merkityksensä (esim. Lumley ja Armstrong 2005; Marshall ja Toffel 2005; Mebratu 1998). Käsitteenä kestävyys on monimerkityksellinen ja usein myös väljästi tulkittu. Kuten Heikkurinen $(2014,10)$ on osuvasti todennut, käsite "saa uuden merkityssisällön käyttäjien, käyttötapojen ja käyttötarkoitusten mukaan".

Kestävyyden käsitteeseen sisältyy eräänlainen paradoksi. Yhtäältä sitä on vaikeaa olla käyttämättä, mikäli halutaan puhua hedelmällisesti elävien järjestelmien suurimmista haasteista. Kestävyyden ydinidea - kyky jatkaa tärkeäksi nähtyä toimintaa - on intuitiivisesti helposti ymmärrettävissä. Itse termiin sisältyy myös niin vahvoja ja positiivisia mielleyhtymiä, ettei siitä kannata luopua. Millä muulla termillä voitaisiin yhtä elegantisti kuvata esimerkiksi niitä haasteita, jotka liittyvät ihmiskunnan toiminnan saattamiseen materiaalisesti, sosiaalisesti ja ekologisesti uusiutumiskykyiseksi jo hupenevien luonnonvarojen ja biodiversiteetin olosuhteissa? Toisaalta juuri näiden ominaisuuksien vuoksi käsitettä myös käytetään kaikkialla. "Kestävyydellä" voidaan tarkoittaa käytännössä mitä tahansa ja sen avulla voidaan yrittää saada positiivinen lataus lähes asialle kuin asialle. Kestävyydestä onkin tullut ennemmin yleistermi, instrumentti ja tyhä merkitsijä kuin 
spesifi käsite. Tällainen niin sanottu heikko käsitys kestävyydestä on pitkälti korvannut vahvan käsityksen, jossa tarkastellaan konkreettisesti kestämisen luonnetta ja tapahtumista (ks. Heikkurinen 2014; Neumayer 2013). Toisin sanoen kestävyyttä ei oteta käsitteenä kovinkaan vakavasti.

Mutta entä jos kestävyyden käsite otettaisiin hyvin vakavasti - jos kestävyydestä puhuttaisiinkin johdonmukaisesti vahvassa mielessä? Missä asiayhteyksissä kestävyydestä olisi mielekästä puhua ja missä ei? Millaisia ilmiöitä ja dynamiikkoja kestävyydellä olisi mielekästä kuvata ja millaisia ei? Mikä tosiasiallisesti lisää erilaisten asioiden kestävyyttä ja mikä ei? Millaisia vaikutuksia kaikella tällä olisi tieteellisen tutkimuksen käytäntöihin, yhteiskunnallisiin instituutioihin, yleisiin ajattelutapoihin tai vaikkapa maailmanpolitiikkaan? Entä miten juuri poliittisen talouden tutkimuksen - kestävyyttä historiallisesti ensimmäisenä systemaattisesti tarkastelleen tieteenalan (Lumley ja Armstrong 2004) - tulisi vastata tällaisiin kysymyksiin?

Vastaaminen edellä kuvattuihin kysymyksiin oli Poliittisen talouden tutkimuksen seuran keväällä 2015 Lapin yliopistolla järjestämän monitieteellisen Kestävä talous -seminaarin pääasiallinen tarkoitus. Nyt lukemasi Poliittinen talous -lehden Kestävä talous -symposium pohjautuu kyseisessä seminaarissa pidettyihin esitelmiin. Symposiumin artikkelit käsittelevät poliittisen talouden tutkimuksen kannalta keskeisiä aiheita. Symposium on kuitenkin tarkoitettu huomattavasti laajemmalle ja monitieteelliselle lukijajoukolle. Se sisältää niin tieteenfilosofian, oikeustieteen, politiikan tulkitsevan analyysin kuin kauppatieteellisen tutkimuksenkin kannalta oleellisia näkökulmia.

Symposium koostuu johdantoartikkelin lisäksi kahdesta alkuperäisartikkelista ja kahdesta katsausartikkelista. Ensimmäisessä alkuperäisartikkelissa Tomi Tuominen tarkastelee kestävyysretoriikkaa niin kutsutussa budjettikurisopimuksessa sekä arvioi, missä määrin sopimusta voidaan pitää poliittis-oikeudellisesti kestävänä (Tuominen 2015). Toisessa alkuperäisartikkelissa Tuomas Kuhmonen, Hanna Partio ja Irene Kuhmonen tulkitsevat EU:n maatalouspolitiikan kehitystä kestävän kehityksen periaatteiden tulkintakehyksessä sekä pohtivat, missä määrin periaatteita voitaisiin hyödyntää politiikkatoimenpiteiden suunnittelussa, laatimisessa ja arvioinnissa (Kuhmonen ym. 2015). Ensimmäisessä katsausartikkelissa Teppo Eskelinen ja allekirjoittanut (Ville-Pekka Sorsa) tarkastelevat tieteenfilosofisesta näkökulmasta kestävyyden ominaisuuden tutkimiseen liittyviä 
haasteita ja rajoituksia (Eskelinen ja Sorsa 2015). Toisessa katsausartikkelissa Lotta Aho ja Maarit Laihonen pohtivat, onko kestävän kehityksen periaatteiden saavuttaminen mahdollista yritystoiminnassa talouskasvua edistävän uusliberaalin kansainvälisen järjestyksen piirissä (Aho ja Laihonen 2015).

Tämän kirjoituksen tarkoituksena on sekä lyhyesti johdatella lukijat kestävyyden käsitteeseen ja erikoisnumeron antiin että pohtia hieman tarkemmin sitä, mitä kestävyyden käsitteen vakavasti ottamisessa on panoksena. Aloitan esittelemällä lyhyesti käsitteen erilaisista käyttötavoista ja asiayhteyksistä tehtyä tutkimusta. Tämän jälkeen tarkastelen symposiumin annin valossa sitä, millaisia mahdollisuuksia ja rajoitteita kestävyyden käsitteen vakavasti ottamiseen vahvassa mielessä liittyy. Pohdin kestävyyttä erikseen ominaisuutena ja tieteellisenä tutkimuskohteena, yhteiskunnallisena tulkintakehyksenä sekä politiikkaideana.

\section{Kestävyyden käsite ja sen käyttöyhteydet}

Etymologisesti tarkasteltuna termi sustainable viittaa niin kantokykyyn (bearable, 1610-luku), puolustettavuuteen (defensible, 1840-luku) kuin kykyyn jatkaa toimintaa jollain tietyllä tasolla (1960-luku) (Etymonline 2015). Kestävyyden systemaattisempi käsite (sustainability) on esiintynyt niin tieteellisessä tutkimuksessa, julkisessa keskustelussa kuin politiikassakin. Kestävyyden nykykäsitteiden mukaisia ideoita on esiintynyt implisiittisesti useissa eri uskonnoissa ja perinteissä jo kauan ennen eksplisiittisen käsitteen syntyä (Mebratu 1998). Vastaavia ideoita hyödynnettiin systemaattisesti jo 1700- ja 1800-luvun poliittisen talouden tutkimuksessa (Lumley ja Armstrong 2004). Eksplisiittinen käsite vakiintui osaksi julkista keskustelua 1970-luvun alun kasvun rajat -diskurssien myötä. Politiikassa se vakiintui Gro Harlem Brundtlandin johtaman YK:n Ympäristön ja kehityksen maailmankomission vuonna 1987 julkaiseman raportin Yhteinen tulevaisuutemme myötä. Tämän jälkeen lähes jokainen kansainvälinen organisaatio, yritys ja tutkimusryhmä on määritellyt käsitteen uudelleen (Marshall ja Toffel 2005).

Kestävyyden käsitteen ja idean luonteesta ja käytöstä on tehty lukuisia tieteellisiä katsauksia (mm. Dixon ja Fallon 1989; Heikkurinen 2014; Lélé 1991; Lumley ja Armstrong 2005; Marshall ja Toffel 2005; Mebratu 1998). 
Näiden perusteella käsite on varsin erilainen niiden käyttöyhteydestä riippuen. Mebratun (1998) mukaan käsitteen sisältö on pitkälti riippuvaista sen esittäjätahosta. Kestävyys esiintyy tässä mielessä poliittis-institutionaalisena ideana, ideologiana ja akateemisena tutkimuskohteena. Ensimmäisiä esittävät muun muassa poliitikot, kansainväliset organisaatiot ja kansalaisjärjestöt. Toisia puolestaan löytyy erilaisista poliittisista ideologioista ja teoreettisista paradigmoista, kuten vaikkapa ekososialismista tai ekofeminismistä. Kolmannet esiintyvät tieteellisessä tutkimuksessa, joskin eri tieteenaloilla eri muodoissa ja erilaisista normatiivisista näkökulmista tarkasteltuna.

Esittäjän mukaan käsityksiä luokitteleva näkökulma on siitä ongelmallinen, ettei siinä voida välttää limittäisyyksiä. Esimerkiksi normatiivisessa tutkimuksessa kestävyys voi esiintyä kaikissa kolmessa mielessä. Kestävyyden käsitteen käyttöä onkin luontevampaa tarkastella sen kautta, millainen funktio käsitteelle annetaan. Ensimmäisessä mielessä kestävyys voidaan ymmärtää jonkin asian ominaisuutena (esim. Heikkurinen 2014). Tämän ominaisuuden tarkastelu "vahvassa mielessä" vaatii aina hyvin selkeän käsityksen tutkittavasti kohteesta, selkeän teoreettisen viitekehyksen sekä näiden pohjalta tehtävän formaalin analyysin (Christen ja Schmidt 2011; tässä symposiumissa Eskelinen ja Sorsa 2015). Tässä mielessä kestävyys ominaisuutena voidaan ymmärtää luontevasti juuri tieteellisen tutkimuksen kohteeksi.

Toisessa mielessä kestävyys voidaan ymmärtää laajemmin tulkinnallisena viitekehyksenä tai spesifinä diskurssina (Christen ja Schmidt 2011). Tähän viitekehykseen kuuluu usein utooppisia piirteitä, normatiivisia kategorisointeja ja tulevaisuuteen kohdistuva narratiiveja (Harlow, Golub ja Allenby 2011). Tähän luokkaan kuuluvat muun muassa YK:n kestävän kehityksen periaatteet, joiden kantavana ideana oli antaa käsitteellisiä työkaluja sen arvioimiseksi, miten (ihmislajin) tulevat sukupolvet voisivat tyydyttää omat tarpeensa (WCED 1987). Nämä periaatteet esimerkiksi jaottelivat kehityksen ekologiset, sosiaaliset ja taloudelliset ulottuvuudet.

Kolmannessa mielessä kestävyys voidaan ymmärtää politiikkaideana tai yleisenä, mutta eksplisiittisenä diskurssina, joiden sisältö voi vaihdella merkittävästi asiayhteydestä toiseen (Cox ja Béland 2013). Kestävyys voidaan ymmärtää tässä mielessä joko tyhjänä merkitsijänä, joka saa merkityksensä vain suhteessa muihin asioihin (esim. Davidson 2010), tai yhteiskunnallisia ongelmia, niiden ratkaisukeinoja tai taustaoletuksia 
yhteen keräävänä otsikkona (Cox ja Béland 2013; Sorsa 2014). Näissä ei kuitenkaan ole kyse vain puhtaasti symbolisista suhteista, vaan eräänlaisista "magneeteista", joiden taakse erilaiset intressit ja ideologiat voivat koalitioina asettua (Béland ja Cox 2015).

Yksi symposiumin toimittamisen kantavia motiiveja on ollut se, että näissä käyttöyhteyksissä käytetään harvoin kestävyyttä käsitettä vahvassa mielessä. Aiemmassa tutkimuksessa vahvan ja heikon kestävyyden erolla viitataan erilaisiin käsityksiin YK:n kestävän kehityksen periaatteista (Neumayer 2013). Näitä käsityksiä voidaan vertailla pääoman metaforan kautta (Heikkurinen 2014). Heikon kestävyyskäsityksen mukaan taloudellinen, sosiaalinen ja ekologinen pääoma ovat substituutteja. Kestävyyttä voidaan toisin sanoen suhteellisesti lisätä vai vähentää monien eri pääoman lajien avulla. Tässä mielessä ei kuitenkaan voida osoittaa, onko jokin todella kestävää vai ei (eli kestääkö se vai ei). Vahvan käsityksen mukaan pääomien lajit eivät ole korvattavissa. Vahvan kestävyyskäsityksen mukaan jokainen pääoman laji sisältää omat kriteerinsä absoluuttiselle kestävyydelle. Ainoastaan sellainen toiminta tai kehitys, jonka seurauksena pääoman eri lajit eivät hupene, on tosiasiallisesti kestävää.

Symposiumin tarkoituksena on laajentaa pohdinta kestävyyden vahvasta käsitteestä myös kestävyyteen ominaisuutena ja politiikkaideana. Esittelen seuraavaksi symposiumin antia sen valossa, millaisia näkökulmia sen sisältämät artikkelit nostavat kestävyyden vahvan käsitteen vakavasti ottamiseen käsitteen kolmen käyttöyhteyden ja funktion mukaisesti.

\section{Kestävyys ominaisuutena ja tutkimuskohteena}

Kestävyyden ottaminen vakavasti tutkimuskohteena tarkoittaa sitä, että tieteellisessä tutkimuksessa tarkastellaan systemaattisesti, kestääkö jokin asia vai ei. Kestävyys viittaa tässä mielessä tutkittavan asian ominaisuuksiin ja piirteisiin, jotka saavat asian kestämään eri olosuhteissa. Kestävyys näyttäytyy vain yli ajan ja olosuhteiden muuttuessa. Kuten toteamme Teppo Eskelisen kanssa symposiumiin kirjoittamassamme katsausartikkelissa (Eskelinen ja Sorsa 2015), kestävyys on vaativampi tutkimuskohde kuin esimerkiksi jatkuvuus tai resilienssi. Kestävyyden tutkiminen vaatii aina sen tunnistamista, mikä tuottaa kestämistä. Kestävyydessä ei ole kyse 
pelkästä kyvystä jatkua, vaan myös sitoutumisesta tämän kyvyn käyttöön ja ylläpitoon.

Kestävyyden tutkiminen ominaisuutena vahvassa mielessä vaatii ainakin kolmea asiaa. Ensinnäkin se vaatii jatkuvuuden ja muutoksen rajanvetoa. Käsite pakottaa määrittelemään asialle jonkinlaisen "ydinidentiteetin" (esimerkiksi maanviljely tiettynä materiaalisena prosessina), joka on pidetty tai oletetaan pidettävän ennallaan ajan kuluessa - muussa tapauksessahan kyse olisi muutoksesta, ei kestämisestä. Samalla se kohdistaa huomion sellaisiin identiteetin muutoksiin, jotka johtuvat sen ympärillä olevien olosuhteiden muutoksista. Jotta olosuhteita voitaisiin havainnoida, on analyysin sisällettävä vahva käsitys siitä järjestelmästä, jonka piirissä tutkittu asia esiintyy ja jonka kautta sen identiteetti määrittyy. Toiseksi käsite vaatii tunnistamaan kantokyvyn rajat, joiden sisäpuolella identiteetti on aktiivisesti pidettävä, jotta sen olemassaolo voisi jatkua. Tässä mielessä käsite vetää rajan jatkuvuuden systemaattisesti mahdollistavien tekijöiden ja uhkien välille. Kolmanneksi käsitteen on tunnistettava ne mekanismit, joiden kautta identiteettiä muutetaan kantokyvyn takaamiseksi. Kutsumme tätä katsausartikkelissamme kestävyyden hallintajärjestelmäksi. Kaikkiin näihin liittyy myös rajanveto relevanttien ja irrelevanttien tekijöiden välillä. Tämän johdosta kestävyys on aina erittäin vahvasti teoriasidonnainen tutkimuskohde. Erilaiset kestävyyskäsitykset ja mahdolliset koulukunnat voidaan tunnistaa siitä, millaiset tekijät se näkee relevanteiksi näiden kolmen ulottuvuuden osalta.

Kestävyys ominaisuutena on vaativa tutkimuskohde siksi, ettei sen tieteellisellä tutkimuksella pystytä välttämättä vastaamaan tyydyttävästi juuri tieteelle esitettyihin kysymyksiin. Kestävyys on asian ominaisuus, joka voidaan havaita ja jonka luonne analysoida empiirisesti vasta jälkikäteen. Mitään asiaa ei siis voida määritellä etukäteen kestäväksi - asia voi vain osoittautua sellaiseksi. Kestävyydestä puhuminen vaikuttaa kuitenkin yhteiskunnallisesti relevantilta vain, jos se tehdään etukäteen. Mitä hyötyä kestävyyden käsitteestä olisi, ellei jotain vaihtoehtoa voida väittää kestäväksi ja toista kestämättömäksi? Tällaisiin teemoihin ei voida ottaa kantaa kestävyyden tutkimuksella, vaan ainoastaan kestävyyttä arvioimalla.

Kuten artikkelissamme tuomme esiin, kaikki aprioriset kestävyyden arviot, joiden avulla edellä mainitun kaltaisia vertailuja voidaan tehdä, ovat vahvasti aksiomaattisia, useita normatiivisia sitoumuksia sisältäviä 
ja yhteiskunnallisten kysymysten osalta myös vahvasti poliittisia. Näiden oletusten uskottavuus ei ole yhteiskunnallisten eli poliittisten, taloudellisten, sosiaalisten ja kulttuuristen kysymysten osalta koskaan vain tieteellinen kysymys. Uskottavuus riippuu yhtä lailla siitä, päätetäänkö oletusten mukaisen maailman tuottamiseen sitoutua. Mitä vähemmän tutkimuksessa avataan sen sisältämää käsitystä yhteiskunnasta, sen epäluotettavampaa ja irrelevantimpaa tutkimus on. Mitä enemmän tätä tehdään, sitä suurempi on kuitenkin myös mahdollisuus, että tutkimus saa performatiivisia tai vastaperformatiivisia piirteitä. Toisin sanoen arvio on epämääräinen ja epäluotettava, muuttuu poliittiseksi toiminnaksi tuottamalla sen kuvauksen mukaista maailmaa tulevaisuudessa tai sitten menettää koko perustansa saamalla ihmiset vastustamaan tätä maailmaa. Mikään näistä tuskin vastaa kestävyyden tieteelliseen tutkimukseen kohdistuviin odotuksiin täysimääräisesti.

Tämä ei kuitenkaan ole ainoa syy sille, miksi kestävyyden ominaisuuden tutkiminen vahvassa mielessä on haastavaa. Tunnistamme katsausartikkelissamme kaksi keskeistä tutkimusprosessiin liittyvää syytä. Ensinnäkin kestävyyden tutkimuksessa itse tutkimuskohde helposti "karkaa" tutkijalta. "Jälkikäteisen" empiirisen tutkimuksen osalta jää aina jokseenkin epäselväksi, pätevätkö kestävyyttä tuottavat mekanismit itse tutkimuskohteeseen eli siihen, minkä kestävyyttä on tutkittu, enää tulevaisuudessa. Kestävyyden arviossa puolestaan joudutaan joko määrittelemään hyvin epäselvästi itse asia, jonka kestävyyttä tarkastellaan, tai sitten jättää käytännössä tutkimatta ne emergentit ominaisuudet, jotka saavat asian jatkumaan uudenlaisissa olosuhteissa. Toisin sanoen tutkimuksessa ei voida koskaan esittää täsmällisesti, minkä tarkalleen ottaen on tarkoitus kestää tai miksi se kestäisi.

Toiseksi kestävyyden tarkastelu ei ole mielekästä kaikkien asioiden suhteen. Kuten todettua, kestävyyden tutkiminen vaatii selkeää tutkittavan asian ydinidentiteetin määrittelyä sekä jonkinlaisen hallintajärjestelmän olettamista. Ydinidentiteetin määrittely sopivassa muodossa ja laajuudessa on hankalaa. Kuten artikkelissa tuomme esiin, liian kapeat määritelmät osoittautuvat helposti irrelevanteiksi, kun taas liian laajat määritelmät ovat ylipäätään liian suuria asioita tutkittavaksi. Hallintajärjestelmän määritelmään liittyy samanlaisia ongelmia. Mitä kapeammaksi hallintajärjestelmä oletetaan, sitä vähemmän tulevaisuuden kehityskulkuja voidaan tunnistaa ja sitä epävarmemmaksi arvio jää. Mitä laajemmaksi se oletetaan, sitä 
epäluotettavammaksi oletukset niin tulevaisuuden kehityskuluista kuin järjestelmään sitoutumisesta muuttuvat. Oletettavan hallintajärjestelmän on oltava sekä sellainen, joka mahdollistaa ydinidentiteetin hallinnan, että uusinnettavissa. Hallintajärjestelmäksi ei siis ole mielekästä määritellä esimerkiksi sellaista järjestelmää, joka on luonteeltaan itsetuhoinen.

Edellä sanotun perusteella vaikuttaa siltä, että kestävyys ominaisuutena on hyvin rajallinen tutkimuskohde. Kaikessa kestävyyden tutkimuksessa on epäilemättä tehtävä tutkimuksen normatiiviset sitoumukset ja rajallisuus selkeäksi. Jälkikäteisessä tai "aidossa" kestävyyden tutkimuksessa tutkittavan asian identiteetin on oltava mielekäs eli selkeä ja hallittavissa oleva. Tällöinkin tutkijan on kuitenkin myös tiedostettava tarkastelunsa kohteen mahdollinen epämääräisyys ja koko tutkimusasetelman vahva teoriasidonnaisuus. Etukäteisessä kestävyyden arviossa ei puolestaan vaikuttaisi olevan mielekästä tarkastella mitään sellaista asiaa, joka on koska tahansa päätettävissä toisin, ainakaan muussa kuin normatiivisen tutkimuksen mielessä. Onkin aiheellista kysyä, tulisiko missään muussa kuin normatiivisessa tutkimuksessa ylipäätään pyrkiä arvioimaan kestävyyttä.

\section{Kestävyys tulkinnallisena viitekehyksenä}

Kestävyys tulkinnallisena viitekehyksenä voidaan ajatella kestävyysdiskursseina, jotka määrittelevät sisäisesti ristiriidattomia ja uusiutumiskykyisiä kokonaisuuksia. Ne samalla mahdollistavat aikaa kestävien käytäntöjen, järjestelmien tai prosessien luomisen. Toisin kuin kestävyys ominaisuutena, viitekehykset eivät kuitenkaan ota kantaa siihen, sitoudutaanko tällaisten käytäntöjen, järjestelmien tai prosessien luomiseen. Tunnetuin kestävyysdiskurssi on peräisin Brundtlandin komission vuonna 1987 esittämästä kestävän kehityksen periaatteista (WCED 1987). Kestävän kehityksen periaatteet ovat tarkoitettu metatason viitekehykseksi, jonka tarkoituksena on saada näkemään ihmisten toiminnan seurauksia ja yhteyksiä erilaisten toimien välillä. Kestävyys on samalla ideaali, joita kohti kehityksen tulisi suuntautua. Periaatteet ohjaavat tarkastelemaan samanaikaisesti toiminnan monia ulottuvuuksia. Tyypillisin kategorisointi kohdistaa tarkastelun 
kehityksen ekologisiin, sosiaalisiin ja taloudellisiin ulottuvuuksiin.

Kestävän kehityksen diskurssi voidaan ottaa vakavasti kahdessa eri mielessä. Ensimmäisessä mielessä voidaan pohtia, millainen käsitys kestävyydestä sisältyy kestävän kehityksen periaatteisiin eli missä mielessä kestävän kehityksen periaatteiden mukaan hahmotettu toiminta on kestävää. Toisessa mielessä voidaan pohtia, millainen käsitys kestävyydestä sisältyy käsitteen erottelemiin kestävän kehityksen eri ulottuvuuksiin ja millä ehdoilla tällainen käsitys todella kestäisi.

Sneddonin (2000) mukaan YK:n kestävän kehityksen käsite oli tullut tiensä päähän jo 20 vuotta sitten sisäisten ristiriitojen ja aukkojen takia. Kestävän kehityksen tulkinnallisen viitekehyksen merkittävin ongelma on, ettei se sisällä riittävän vahvaa käsitystä toimintaa ohjaavista tekijöistä (Christen ja Schmidt 2011). Toisin sanoen kestävän kehityksen periaatteista puuttuu selkeän hallintajärjestelmän määritelmä. Myös esimerkiksi Marshall ja Toffel (2005) ovat argumentoineet, ettei arvoja, uskomuksia tai esteettisiä preferenssejä tulisi sisällyttää kestävyyden viitekehykseen. Paitsi että nämä tekijät ovat aina muutettavissa, jää niiden analyysi ilman niiden roolia toimintaa ohjaavissa mekanismeissa myös irrelevantiksi.

Tässä mielessä voidaankin sanoa, etteivät YK:n kestävän kehityksen periaatteet ole koskaan riittäviä määritelmän mukaisen kestävyyden saavuttamiseksi. Kestävän kehityksen periaatteisiin pätee siis sama huomio kuin kestävyyden tutkimukseen: kestävää kehitystä yleisesti ei ole olemassa, vaan kestävä kehitys on aina jonkin konkreettisen asian ja järjestelmän kestävää kehitystä. Jotta kestävyyteen vahvassa mielessä koskaan päästäisiin käsiksi, on määriteltävä selkeästi, millaisen hallintajärjestelmän piirissä kestävyys on tarkoitus saavuttaa.

Hallintajärjestelmän sisällyttäminen kestävän kehityksen periaatteisiin ei kuitenkaan ole ongelmatonta. Tuomas ja Irene Kuhmonen ja Hanna Partio tulkitsevat symposiumin alkuperäisartikkelissaan Euroopan unionin maatalouspolitiikan kehitystä kestävän kehityksen periaatteiden valossa. Kirjoittajien mukaan kestävän kehityksen periaatteet voisivat parhaiten toimia politiikan suunnittelun ja arvioinnin metatason viitekehyksenä, jonka avulla voitaisiin systemaattisesti hahmottaa maatalouspoliittisten politiikkatoimenpiteiden erilaisia vaikutuksia - toisin sanoen kestävyytenä heikossa mielessä. Kestävän kehityksen periaatteita vahvassa mielessä ei kuitenkaan välttämättä voida ottaa mielekkäällä tavalla esimerkiksi 
politiikan päämääräksi. Kestävän kehityksen eri ulottuvuuksille on kirjoittajien mukaan mahdotonta määritellä selkeitä "normatiivisia pisteitä" tai edes löytää niiden välille yhteisiä mittareita, joiden kautta tosiasiallisen kestämisen analyysia voitaisiin analysoida. Kirjoittajien mukaan kestävä kehitys on maatalouspolitiikan tapauksessa myös erilaista eri mittakaavoissa ja paikallisissa ja ajallisissa konteksteissa. Näiden yhteensovittaminen ei välttämättä ole edes loogisesti mahdollista yhden viitekehyksen puitteissa.

Kuhmosten ja Partion pohdinnasta voidaan tehdä pidemmälle menevä johtopäätös: yhden hallintajärjestelmän olettaminen ei vaikuttaisi olevan mielekästä, jos periaatteiden saavuttaminen vaatii poliittisista syistä monia hallintajärjestelmiä. Lisäksi on huomattava, että erilaisten hallintajärjestelmien olettaminen ja tuottaminen ei ole vain analyyttinen, vaan myös puhtaasti poliittinen kysymys. Juuri tällainen erilaisten hallintajärjestelmien ominaisuuksien tunnistamiseen ja valikointiin liittyvä poliittisuus puuttuu kokonaan YK:n kestävän kehityksen periaatteista. Periaatteiden olisi siis otettava hallintajärjestelmiin kantaa kahdessa mielessä, jotta ne edustaisivat kestävyyttä vahvassa mielessä. Jos periaatteita luetaan vahvassa mielessä, voidaan toki sanoa, että mikäli esimerkiksi ihmiskunnan (kulutus)kulttuurit ovat ekologisesti kestämättömiä, ei kulttuurisen kestävyyden edistäminen perinteiden vaalimisen mielessä lisää toiminnan kestävyyttä. Periaatteet kuitenkin vaikenevat sen suhteen, mitä perinteistä ja kenen perinteitä on ylipäätään mahdollista ja tulisi muuttaa.

Kestävän kehityksen viitekehyksen kehittämistä kuitenkaan tule jättää pelkästään erilaisten toimiala-, maa- tai esimerkiksi aluekohtaisten hallintajärjestelmien ja niiden välisten suhteiden määrittelyn varaan. Tämä johtuu siitä, että kansainvälinen makrotason hallintajärjestelmä joka tapauksessa ehdollistaa ja kannustaa näitä järjestelmiä. Lotta Aho ja Maarit Laihonen osoittavat katsausartikkelissaan, ettei nykymuotoinen uusliberaali, yrityksiä ja markkinoita korostava kansainvälisen ympäristöhallinnon järjestämistapa sisällä perustavanlaatuisia juridisia tai tietoon liittyviä esteitä ekologisesti kestävän liiketoiminnan aikaansaamiseksi. He esittävät, että syyt siihen, miksi kestävään liiketoimintaan ei ole siirrytty, ovat luonteeltaan ideologisia ja siten poliittisia. He kuitenkin myös osoittavat, etteivät vallitsevat poliittiset ideologiat tai ympäristöhallinnon järjestämistapa myöskään sisällä kannustimia ekologisesti kestävien, vaan pikemminkin päinvastaisiin eli luonnonvarojen kulutusta lisäävien toimintatapojen omaksumiseen. Tässä 
mielessä nykymuotoinen uusliberaali hallintajärjestelmä voidaan tulkita jossain määrin itsetuhoiseksi. Mikäli järjestelmä on tällainen, ei sen sisällyttäminen kestävän kehityksen tulkinnalliseen viitekehykseen ole perusteltua.

Toinen tapa käsittää kestävän kehityksen tulkinnallinen viitekehys on tarkastella asioita systemaattisesti kestävyyden eri ulottuvuuksien tai erilaiset logiikat sisältävien "kestävyyksien" näkökulmasta. Symposium ei sisällä artikkelia, joka käsittelisi eksplisiittisesti sitä, miten kestävyys vahvassa mielessä voitaisiin ottaa osaksi tällaista analyysia. Aihetta kuitenkin sivutaan useammassa artikkelissa. Kuhmosten ja Partion artikkelissa EU:n maatalouspolitiikan sisältämiä kestävyyslogiikoita luokitellaan, mutta ainoastaan kestävyyden heikossa mielessä. Pohdinta kestävyydestä vahvassa mielessä sisältyy artikkelissa teoreettiseen pohdintaan. Ahon ja Laihosen artikkelissa tarkastellaan ympäristöllistä kestävyyttä vahvasta näkökulmasta, mutta analyysi kohdistuu pääasiallisesti liiketoiminnan hallintajärjestelmän tarkasteluun liiketoiminnan systemaattisen tulkinnan sijaan. Tomi Tuomisen artikkelissa pohditaan erilaisten kestävyyksien epäsuhtaa. Itse kestävyyttä ei kuitenkaan tässä yhteydessä käsitellä tulkinnallisena viitekehyksenä, vaan tietyn hallintajärjestelmän sisäisenä politiikkaideana ja ominaisuutena.

Esitän itse tässä yhteydessä yhden teoreettisen hypoteesin jatkotutkimusta varten. Kuten todettua, kestävän kehityksen periaatteiden lukemiseen vahvassa mielessä on sisältynyt ajatus kestävyyden ekologisen, taloudellisen, sosiaalisen ja muiden ulottuvuuksien analyysista pääoman lajeina, joita ei voida pitää substituutteina (Neumayer 2013). Mikäli periaatteet kuitenkin ajatellaan tiukemmin tulkinnan viitekehyksenä, voidaan ulottuvuudet ajatella "kestävyyksien" tai kestävyyden pääomalajien sijaan kukin omana kestävyyden hahmottamisen logiikkana tai kestävyyden kielenä. Tarkoitan tällä sitä, että mitä tahansa asiaa ja kestävyyttä sen ominaisuutena voidaan hahmottaa eri näkökulmista, jotka vain esittävät asian identiteetin ja kestävyyden ominaisuudet kukin omalla kielellään. Kun tämä ymmärretään kestävyyden vahvasta näkökulmasta, voidaan esimerkiksi sanoa, että ekologista ja sosiaalista kestävyyden ulottuvuutta ei tulisi erottaa toisistaan: on vain ekologinen ja sosiaalinen tapa hahmottaa yksi ja sama kestävyyden ominaisuus.

Esimerkiksi ekologisen kestävyyden tarkastelussa lähtökohtana ovat elävät järjestelmät eli organismit ja aineet, näiden väliset interaktiot sekä elämän uusintamiseen tarvittavat tarpeet. Analyysi on luonteeltaan materiaalista ja 
sen perusyksikkö on jatkuvuuden tuottavat interaktiot. Kaikki kysymykset tulisi tällöin esittää näistä näkökulmista. Lähestymistapa on yleinen muun muassa organisaatiotutkimuksessa (Hannan ja Freeman 1977). Myös taloudellisen kestävyyden kieli kiinnittää huomion interaktioihin. Sen tarkastelun kohteena ei kuitenkaan ole tarpeet ja elämän uusintaminen, vaan halut ja resurssien käyttö. Sosiaalisen kestävyyden perustana voisivat taas olla ihmisten välisten suhteiden ja käytäntöjen institutionalisoituminen, poliittisen kestävyyden perustana taas hyväksyttävyys ja hallittavuus. Sosiaalitieteiden ja politiikkatieteiden eri koulukunnat painottavat toki varsin erilaisia lähtökohtia analyysiin, eikä näiden kestävyyksien kielien muotoileminen yksiselitteisesti luultavasti ole edes mahdollista (ks. Kautto ja Metso 2008).

Tällainen lähestymistapa voisi olla ainakin kahdella eri tavalla hyödyllinen. Ensinnäkin monien erilaisten asioiden kääntäminen eri kielille helpottaa tieteidenvälistä keskustelua, mikä puolestaan helpottaa kestämisen mekanismien mahdollisimman laajamittaista tunnistamista ja hallintajärjestelmien rajojen määrittelemistä. Jos asia on määriteltävissä vain yhdellä kestävyyden kielellä, ei oletetun hallintajärjestelmän luultavasti tarvitse olla kovinkaan laaja. Toiseksi lähestymistapa tekisi vahvemman rajanvedon sen suhteen, millaisten asioiden kestämisestä on yleisesti ottaen mielekästä puhua ja miten. Mikäli löytyy sellaisia kysymyksiä, joiden kestämisen logiikkaa ei ole hahmotettavissa millään kielellä, ei näiden kestävyydestä ole ylipäätään mielekästä puhua. Mikäli taas joitain kysymyksiä ei ole "käännettävissä" jollekin kestävyyden kielelle, ei tällaiselle kielelle ole tarvetta. Mikäli esimerkiksi atollin asutuksen kestämistä ja tätä uhkaavaa merenpinnan nousua tuottavia toimia ympäri maailman ei ole määriteltävissä esteettisestä näkökulmasta, ei esteettinen näkökulma ole sopiva kestävyyden hahmottamiseksi (Morton 2007). Koska ihmisen toimintaan liittyy kuitenkin aina esteettisiä ulottuvuuksia ja koska kaikki ekologinen tutkimus sisältää jonkinlaisen ihmisen roolin määritelmän, on esteettinen kieli täysin mahdollinen - joskaan ei luultavasti se hedelmällisin - tulkintakehys ihmisten toimintaa koskevan kestävyyden analyysiin. 


\section{Kestävyys politiikkaideana}

Viimeinen tässä symposiumissa tarkasteltava kestävyyden käyttöyhteys ja funktio on kestävyys politiikkaideana ja spesifinä diskurssina. Tämä käyttöyhteys poikkeaa muista siten, että kestävyys voi tarkoittaa käytännössä mitä tahansa ideasta riippuen, eikä tällä ole välttämättä mitään tekemistä kestävyyden kanssa vahvassa mielessä. Kestävyyden ottaminen vakavasti politiikkaideana vaatii kuitenkin juuri sen analyysia, missä mielessä ja millä ehdoilla kestäväksi tai kestävyydeksi kutsuttu asia voi tosiasiallisesti kestää. Kestävyyden ottaminen vakavasti politiikkaideana tarkoittaisi myös kestävyyskäsityksen sisäisten epäloogisuuksien, ristiriitojen, aukkojen ja/tai valheellisten piirteiden tunnistamista sekä mahdollisesti käsityksen vertailua jostain tulkinnallisesta viitekehyksestä tai (ominaisuuksia koskevista) tutkimustuloksista johdettuun käsitykseen kestämisestä.

Tomi Tuominen tarkastelee artikkelissaan EU-valtioiden keskenään sopiman budjettikurisopimuksen sisältämää käsitystä julkistalouden kestävyydestä. Tuomisen artikkelin nojalla sopimuksen sisältämä käsitys kestävyydestä on ongelmallinen, mikäli kestävyys ajatellaan vahvassa mielessä kestämisenä. Sopimuksella ei ole merkittävää oikeudellista asemaa, minkä vuoksi sen suorat vaikutukset lainsäädäntöön jäävät luultavasti vähäiseksi. Kestävyyttä ei ole sopimuksessa tarkoitettu preskriptiiviseksi politiikkatoimenpiteeksi, vaan ainoastaan ongelmanmäärittelyksi ja sen laajuuden kuvaamiseksi tarkoitukseksi työkaluksi, jota kukin sopimuksen allekirjoittanut valtio soveltaa haluamallaan tavalla. Tosiasiallisesti sopimus kuitenkin tuottaa samanlaisia talouspolitiikan ajattelutapoja ja politiikkatoimenpiteitä sekä yleisesti ottaen kaventaa valtioiden talouspoliittista toimintamahdollisuuksia. Sopimus itsessään edustaa uudeksi konstitutionalismiksi poliittis-oikeudellista kehitystä, joka EU:n viitekehyksessä syventää integraatiota. Tuomisen mukaan tämä tapahtuu ilman poliittista legitimiteettiä. Poliittisia toimenpiteitä pyritään toisin sanoen tuottamaan oikeuden välinein ilman toimenpiteiden poliittista tahtoa tai oikeutusta.

Tuomisen johtopäätös onkin, että poliittisen legitimiteetin puute tekee budjettikurisopimuksen kestävyyskäsityksestä tosiasiallisesti kestämättömän. Samansuuntaisia tulkintoja voidaan tehdä oikeudellisten rakenteiden luomisen ohella myös julkishallinnon toimintaa koskien (ks. Eskelinen ja Sorsa 2011; 2013). Olen itse kritisoinut toisaalla kotimaista julkistalouden 
kestävyysajattelua myös lukuisista muista syistä (Sorsa 2014). Ajattelussa ongelman perustelu, sen esitetty ilmenemismuoto ja ratkaisukeinot eivät ole loogisesti täysin yhteensopivia. Ajattelun implikoimat politiikkatoimenpiteet heikentävät tosiasiallisesti kestävyyttä, mikäli ne toteutetaan talouden laskusuhdanteessa. Kestävyyden arvioinnin pohjana olevat tarkastelumallit eivät myöskään perustu vallitsevien instituutioiden riittävään analyysiin, jotta käsitys kestävyydestä olisi uskottava. Julkisen sektorin rahoitusasemaa koskevan kestävyyden pohdinta ei ylipäätään vaikuta mielekkäältä ilman lisämääreitä, koska valtiot voivat aina päättää oman rahoitusasemansa määrittelemällä valtion ja keskuspankin suhteen toisella tavalla. Toisin sanoen ongelman ratkaisevaksi hallintajärjestelmäksi on oletettu kapeat hallintamekanismit sisältävä hallintajärjestelmä, vaikka laajemman hallintamekanismien puitteissa itse ongelmaa ei esitetyssä muodossa esiinny.

Julkistalouden rahoitusaseman kestävyys on hyvä esimerkki asiasta, jota koskevia kestävyyden politiikkaideoita on mahdotonta ottaa nykymuodossaan vakavasti kestävyyden vahvassa mielessä. Liiketoiminnan ympäristöllisen kestävyyden ideasta tuskin voidaan sanoa samaa - liiketoiminta ei voi jatkua, mikäli siihen tarvittavia materiaalisia resursseja ei ole saatavilla. Ahon ja Laihosen artikkeli osoittaa, että idean ottaminen vakavasti nykymuotoisen uusliberaalin ympäristöhallinnon puitteissa vaatisi todennäköisesti osakkeenomistajilta ryhtymistä kollektiivisesti ajamaan yritysten yhtiöjärjestysten ja strategioiden muutoksia. Mikäli laajamittaista tahtoa esimerkiksi kiertotalouden välittömään toteuttamiseen vapaaehtoisesti ei löydy kuluttajien, yritysten ja osakkeenomistajien parista, eivät vapaaehtoiset keinot Ahon ja Laihosen mukaan riitä kestävyyden toteuttamiseksi. Lisäksi on muistettava, ettei minkäänlainen pienimuotoinen tai asteittainen muutos välttämättä riitä esimerkiksi ilmaston lämpenemisen hidastamiseksi tai kumoamiseksi.

Liiketoiminnan ympäristöllisen kestävyyden esimerkki osoittaa, että kestävyyden saavuttaminen on hyvin epätodennäköistä ilman, että kestävyyden idea vahvassa mielessä otetaan vakavasti kuin salamaniskusta. Nykyiset hegemonisessa asemassa olevat ideologiat tekevät kuitenkin Ahon ja Laihosen mukaan juuri tästä, samoin kuin vapaaehtoisuuten perustuvien sääntelykeinojen, käyttöönotosta hyvin epätodennäköisiä. Mikäli kestävyyden käsite otetaan poliittisen talouden tutkimuksen näkökulmasta vakavasti, voidaankin epäilemättä sanoa, ettei maailman nykyinen 
poliittis-taloudellinen järjestelmä ole tehnyt samaa. Myös järjestelmän edellytykset tämän tekemiseen vaikuttavat symposiumin annin näkökulmasta vähäisiltä niin ideologisista, käytännöllisistä kuin valtasuhteisiin palautuvista seikoista johtuen. Vaikuttaakin epätodennäköiseltä, että kestävyys otettaisiin vakavasti ilman jonkinlaista laajamittaisen muutoksen mahdollistavaa ekologista tai yhteiskunnallista shokkia. Kestävyyden tutkimuksen kannalta olisi kiinnostavaa tunnistaa, millaisia tällaiset shokit voivat olla luonteeltaan.

\section{Lähteet}

Aho, Lotta ja Laihonen, Maarit. 2015. Kestävän kehityksen kestämätön tragedia. Poliittinen talous, 3:1. http://poliittinentalous.fi/ojs/index.php/poltal/article/ view/39 [Luettu 31.12.2015]

Béland, Daniel ja Cox, Robert Henry. 2015. Ideas as coalition magnets: coalition building, policy entrepreneurs, and power relations. Journal of European Public Policy. Early view. http://www.tandfonline.com/doi/abs/10.1080/13501763.20 15.1115533 [Luettu 30.12.2015]

Christen, Marius ja Schmidt, Stephan. 2012. A formal framework for conceptions of sustainability - a theoretical contribution to the discourse in sustainable development. Sustainable Development, 20:6, 400-410.

Cox, Robert Henry ja Béland, Daniel. 2013. Valence, policy ideas, and the rise of sustainability. Governance, 26:2, 307-328.

Davidson, Mark. 2010. Sustainability as ideological praxis: The acting out of planning's master-signifier. City, 14:4, 390-405.

Dixon, John A. ja Fallon, Louise A. 1989. The concept of sustainability: Origins, extensions, and usefulness for policy. Society \& Natural Resources, 2:1, 73-84.

Eskelinen, Teppo ja Sorsa, Ville-Pekka. 2011. Hyvä talous, Helsinki: Like.

Eskelinen, Teppo ja Sorsa, Ville-Pekka. 2013. The production of institutional facts in economic discourse. World political science review, 9:1, 1-30. 
Eskelinen, Teppo ja Sorsa, Ville-Pekka. 2015. Kestävyyden käsitteen mielekkyys tutkimuksessa. Poliittinen talous, 3:1. http://poliittinentalous.fi/ojs/index.php/ poltal/article/view/36 [Luettu 31.12.2015]

Etymonline. 2015. Sustainable (adj.). http://www.etymonline.com/index. php?term=sustainable [Luettu 30.12.2015]

Hannan, Michael T. ja Freeman, John. 1977. The population ecology of organizations. American Journal of Sociology, 82:5, 929-964.

Harlow, John, Golub, Aaron ja Allenby, Braden. 2013. A review of utopian themes in sustainable development discourse. Sustainable Development, 21:4, 270-280.

Heikkurinen, Pasi. 2014. Kestävyyden käsitteen ulottuvuudet. Tieteessä tapahtuu, $32: 4,10-16$.

Kautto, Mikko ja Metso, Laura. 2008. Sosiaalinen kestävyys - uusi poliittinen horisontti? Yhteiskuntapolitiikka, 73:4, 411-420.

Kuhmonen, Tuomas, Partio, Hanna ja Kuhmonen, Irene. 2015. EU:n maatalouspolitiikka ja kestävä kehitys. Poliittinen talous, 3:1. http:// poliittinentalous.fi/ojs/index.php/poltal/article/view/38 [Luettu 31.12.2015]

Lélé, Sharachchandra. 1991. Sustainable development: A critical review. World Development, 19:6, 607-621.

Lumley, Sarah ja Armstrong, Patrick. 2004. Some of the nineteenth century origins of the sustainability concept. Environment, Development and Sustainability, 6:3, 367-378.

Marshall, Julian D. ja Toffel, Michael W.. 2005. Framing the elusive concept of sustainability: A sustainability hierarchy. Environmental Science \& Technology, 39:3, 673-682.

Mebratu, Desta. 1998. Sustainability and sustainable development: Historical and conceptual review. Environmental Impact Assessment Review, 18:6, 493-520.

Morton, Timothy. 2007. Ecology without nature: Rethinking environmental aesthetics. Cambridge, MA: Harvard University Press. 
Neumayer, Eric. 2013. Weak versus strong sustainability: Exploring the limits of two opposing paradigms 4. Painos. Cheltenham: Edward Elgar.

Sneddon, Christopher. 2000. "Sustainability" in ecological economics, ecology and livelihoods: a review. Progress in Human Geograpyh, 24:4, 521-549.

Sorsa, Ville-Pekka. 2014. Kestävyysvajeen politiikkaidean kritiikki. Politiikka, $56: 2,132-142$.

Tuominen, Tomi. 2015. Budjettikurisopimus - kestävään talouteen pakottaminen oikeuden keinoin. Poliittinen talous, 3:1. http://poliittinentalous.fi/ojs/index. php/poltal/article/view/37 [Luettu 31.12.2015]

WCED [World Commission on Environment and Development]. 1987. Our common future. Oxford: Oxford University Press. 